\title{
PENGEMBANGAN PERANGKAT PEMBELAJARAN STRATEGI QUICK ON THE DRAW DENGAN MASALAH OPEN ENDED UNTUK MENINGKATKAN KEMAMPUAN BERPIKIR KREATIF MATERI PRISMA DAN LIMAS
}

\author{
Nurain Suryadinata \\ Pendidikan Matematika, FKIP Universitas Muhammadiyah Metro \\ E-mail: math@nsdinata15.com
}

\begin{abstract}
The aim of this research to gain the result of developing instructional sets through quick on the draw with open ended problem of pyramid and prism subject validly, practically, and effectively. The learning instrument development using Plomp model. TKKM data processed by $t$ test, and the proportion of z.The instructional sets valid based on the average score of validity: Syllabus 4.0; Lesson Plan 4.2; Supplementary Books 4.3; Students' Worksheets 4.3; and creative thinking test on mathematics was valid, the level of difficulty was balance, and distinctive feature was significant and reliable. The instructional sets were practical by gaining average score 3,87, the implementation of learning process was good. Students and teachers had positive responses. The instructional sets were effective by gaining: students' creative thinking competence of mathematics beyond the KKM; creative thinking abilities of students who were given a quick on the draw learning with open ended problems better than students were given the conventional learning; and the improvement of creative thinking competence of students who were given a quick on the draw learning with open ended problems better than students were given the conventional learning.
\end{abstract}

Keywords: creative thinking; developing instructional sets; open ended; quick on the draw

\section{PENDAHULUAN}

Perkembangan teknologi

dan informasi tidak lepas dari

kemampuan berpikir kreatif

manusia (Siswono, 2009),

sehingga dalam suatu sistem

pendidikan juga harus bisa

mengembangkan kreativitas siswa.

Pentingnya kreativitas juga

dijelaskan oleh Sriraman dkk
(2011) yang mengungkapkan bahwa salah satu tujuan dari setiap sistem pendidikan harus mendorong orang-orang kreatif untuk dapat membuat informasi yang baik, keputusan kritis dan pilihan dalam kondisi yang tidak terduga. Menurut Kwon dkk (2006), kreativitas adalah kemampuan dimensi tinggi 
manusia atau keterampilan untuk memikirkan sesuatu yang baru. Lebih lanjut, Siswono (2009) menjelaskan bahwa berpikir kreatif merupakan suatu kegiatan mental yang digunakan seseorang untuk membangun suatu ide atau gagasan yang "baru" secara fasih dan fleksibel.

Salah satu mata pelajaran yang cukup penting dalam mendorong kreativitas siswa adalah matematika. Menurut Rochmad (2013) pada mata pelajaran matematika banyak materi yang dapat mengantarkan siswa memiliki keterampilan berpikir kritis dan kreatif. Pembahasan mengenai kreativitas matematika lebih ditekankan pada prosesnya, yakni proses berpikir kreatif. Oleh karena itu, kreativitas dalam matematika lebih tepat diistilahkan sebagai berpikir kreatif matematis. Meski demikian, istilah kreativitas dalam matematika atau berpikir kreatif matematis dipandang memiliki pengertian yang sama, sehingga dapat digunakan secara bergantian (Mahmudi, 2010).

Faktor-faktor yang dapat mendukung pembelajaran matematika adalah proses dan tindakan, faktor-faktor pembelajaran, dan karakteristik tugas matematika (Chamberlin, 2009). Berdasarkan pendapat tersebut, terlihat bahwa salah satu faktor yang mendukung pembelajaran matematika adalah karakteristik tugas matematika. Jika dikaitkan dengan kemampuan berpikir kreatif matematis maka salah satu tugas yang dapat digunakan dalam pembelajaran matematika untuk mengembangkan kemampuan berpikir kreatif adalah dengan penggunaan masalah open ended (Pehkonen, 2007).

Pada kenyataannya, Sudiarta (2006) menjelaskan bahwa belum tersedia perangkat pembelajaran berorientasi pemecahan masalah matematika open ended yang memadai, koleksi masalahmasalah matematika sangat terbatas, bahkan belum ada untuk sebagian besar topik-topik penting matematika. Berkaitan dengan perangkat pembelajaran, Siswono (2009) mengemukakan bahwa perangkat pembelajaran yang menekankan berpikir kreatif dalam matematika tidak tersedia. Buku siswa atau LKS yang ada (digunakan di sekolah) cenderung menekankan pada penguasaan konsep dengan tidak memberikan kebebasan siswa berpikir secara mandiri dan kreatif. Adanya 
sumber belajar yang demikian tidak mendorong pengembangan kemampuan berpikir kreatif siswa di kelas, sehingga diperlukan adanya perangkat yang mendukung.

Berdasarkan hasil investigasi awal di kelas VIII SMP Islam Roudlotus Saidiyyah Semarang, diketahui bahwa kemampuan berpikir kreatif matematis siswa masih tergolong rendah. Selain dari hasil tes terhadap kemampuan berpikir kreatif siswa, hasil wawancara dengan guru kelas juga diketahui bahwa guru belum begitu banyak menggunakan masalah-masalah open ended pada pembelajaran di kelas. Dalam penerapannya guru masih mengalami kesulitan jika harus mencari masalah open ended yang ideal, serta perangkat pembelajaran yang mendukung.

Geometri dapat diartikan sebagai cabang matematika yang berhubungan dengan posisi, ukuran, dan bentuk angka. (Mason dkk 2004). Pentingnya Geometri di Indonesia sendiri dapat terlihat dari adanya materi tersebut di setiap tingkat pendidikan. Namun demikian, prestasi belajar geometri siswa masih bisa dikatakan rendah. Salah satu indikasinya dapat dilihat dari hasil
Trends in International Mathematics and Science Study (TIMSS). Berdasarkan hasil dari TIMSS tahun 2011 (Mullis dkk, 2012), dapat diketahui bahwa prestasi belajar geometri siswa kelas VIII di Indonesia berada di urutan ke-39 dengan nilai 377 dari 42 negara yang berpartisipasi. Hal ini cukup memprihatinkan, terlebih lagi hasil tersebut menunjukkan penurunan dari hasil TIMSS tahun 2007.

Salah satu materi geometri di kelas VIII yang banyak digunakan dalam kehidupan sehari-hari adalah bangun ruang. Untuk mencapai tujuan pembelajaran secara maksimal, tidak cukup dengan memberikan soal-soal tertutup, tetapi diperlukan juga pemberian soalsoal open ended yang bisa mengembangkan pola pikir kreatif siswa.

Saat pemberian soal open ended pada proses pembelajaran, jika pembelajaran yang dilakukan cenderung masih teacher-centered maka siswa menjadi pasif di dalam kegiatan pembelajaran. Menurut Trianto (2009) pada pembelajaran teacher-centered siswa tidak diajarkan strategi belajar yang dapat memahami bagaimana belajar, berpikir dan 
memotivasi diri sendiri (self motivation), padahal aspek-aspek tersebut merupakan kunci keberhasilan dalam suatu pembelajaran. Masalah ini banyak dijumpai dalam kegiatan proses belajar mengajar di kelas, oleh karena itu, perlu menerapkan suatu strategi belajar yang dapat membantu siswa untuk memahami materi ajar dan aplikasinya.

Salah satu upaya yang dapat dilakukan adalah dengan menerapkan pembelajaran yang mengarahkan siswa untuk melakukan kegiatan berdiskusi dalam kelompok. Pembelajaran dengan pendekatan kelompok memiliki potensi untuk mempengaruhi prestasi akademik siswa dalam matematika (Dhlamini dan Mogari, 2013; Smith dkk, 2013). Salah satu pembelajaran diskusi kelompok yang dapat diterapkan adalah quick on the draw. Ginnis (2008) menjelaskan bahwa quick on the draw merupakan sebuah aktivitas riset dengan intensif bawaan untuk kerja tim dan kecepatan. Alasan menggunakan quick on the draw diantaranya adalah aktivitas ini mendorong kerja kelompok, membantu siswa untuk membiasakan diri belajar pada sumber lain selain guru, dan sesuai dengan karakter kinestetik yang tidak dapat duduk diam selama lebih dari dua menit.

Berdasarkan penjelasan di atas, maka penelitian ini bertujuan untuk mengembangkan perangkat pembelajaran matematika strategi quick on the draw dengan masalah open ended yang valid, dan praktis, serta efektif dalam meningkatkan kemampuan berpikir kreatif matematis siswa materi prisma dan limas.

\section{METODE PENELITIAN}

Penelitian ini merupakan jenis Research and Development (R\&D) yang mengembangkan perangkat pembelajaran meliputi Silabus, Rencana Pelaksanaan Pembelajaran (RPP), Lembar Kegiatan Siswa (LKS), Buku Suplemen dan Tes Kemampuan Berpikir Kreatif Matematis (TKBKM). Penelitian ini dilakukan di SMP Islam Roudlotus Saidiyyah Semarang Tahun Pelajaran 2013/2014. Populasi penelitian ini adalah siswa kelas VIII. Model pengembangan yang digunakan adalah model pengembangan Plomp (Rochmad, 2012) yang terdiri dari lima tahap yaitu: prelimenary investigation; design; 
realization/construction; test, pengembangan perangkat evaluation and revision; dan pembelajaran dalam penelitian ini implementation. Namun penelitian digambarkan pada gambar 1 .

ini tidak sampai pada tahap implementation, tahap tersebut tidak dilakukan didasarkan pertimbangan bahwa untuk melakukan implementasi yang luas diperlukan keterlibatan siswa yang lebih banyak. Alur

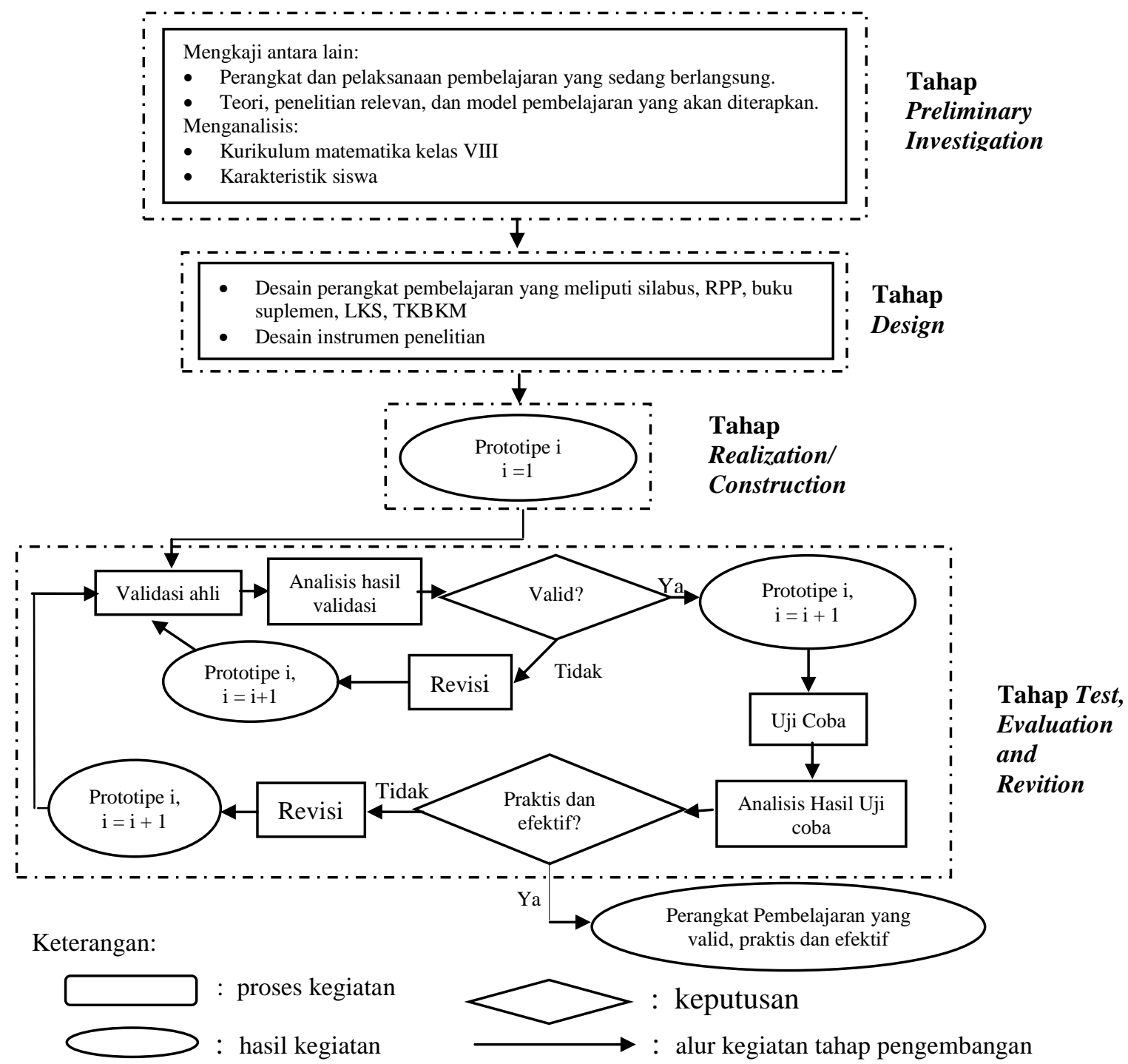

Gambar 1 Skema alur pengembangan perangkat pembelajaran matematika strategi quick on Aksioma the draw dengan masalah open ended 
Kelayakan perangkat pembelajaran yang dikembangkan dilihat dari aspek validitas, kepraktisan, dan keefektifan (Nieveen, 2007). Dalam penelitian ini, perangkat pembelajaran dikatakan memenuhi aspek validitas apabila telah melalui proses validasi ahli dengan skor penilaian mencapai kriteria minimal cukup. Aspek kepraktisan dilihat dari keterlaksanaan perangkat pembelajaran minimal mencapai kategori baik, serta respon siswa dan guru terhadap proses pembelajaran dan perangkat pembelajaran adalah positif. Aspek keefektifan dilihat dari kemampuan berpikir kreatif matematis mencapai KKM, kemampuan berpikir kreatif matematis siswa pembelajaran strategi quick on the draw dengan masalah open ended lebih tinggi daripada siswa pembelajaran konvensional, serta peningkatan kemampuan berpikir kreatif matematis siswa pembelajaran matematika strategi quick on the draw dengan masalah open ended lebih tinggi daripada siswa pembelajaran konvensional.
Metode pengumpulan data menggunakan metode observasi, angket, dan tes. Instrumen penelitian menggunakan lembar validasi, lembar observasi keterlaksanaan perangkat pembelajaran, angket respon siswa dan guru, serta tes kemampuan berpikir kreatif.

Analisis validasi perangkat pembelajaran dilakukan dengan menelaah hasil penilaian validator terhadap perangkat pembelajaran. Analisis data kepraktisan yang digunakan adalah analisis data pengamatan keterlaksanaan perangkat pembelajaran, respon siswa dan guru yaitu dengan cara menghitung jumlah skor tiap indikator dan dibagi dengan banyaknya item pertanyaan. Untuk analisis uji keefektifan, dilakukan uji normalitas dan uji homogenitas. Selanjutnya data nilai tes kemampuan berpikir kreatif matematis dianalisis menggunakan uji $t$ dan uji $z$. Aspek kemampuan berpikir kreatif dilihat dari kefasihan (fluency), keluwesan (flexibility) dan kebaruan (novelty), (Levav dan Leikin, 2009; Kattou dkk, 2012). 


\section{HASIL PENELITIAN DAN PEMBAHASAN}

Tahap preliminary investigation, kegiatan yang dilakukan pada tahap ini adalah menganalisis situasi dan permasalahan yang terjadi pada pembelajaran matematika di SMP yang dalam hal ini adalah SMP Islam Roudlotus Saidiyyah Semarang. Selain itu, dilakukan analisis kurikulum, karakteristik siswa dan kompetensi yang harus dicapai siswa.

Tahap design dilakukan suatu upaya untuk mendesain suatu kemungkinan solusi terhadap masalah yang telah didefinisikan pada tahap investigasi awal. Dari hasil kajian dan tinjauan pada tahap preliminary investigation, dilakukan suatu upaya mengembangkan suatu perangkat pembelajaran yang mendukung karakteristik pembelajaran yang diterapkan dan memuat masalah open ended.

Pada tahap realization/ construction dilakukan penyusunan Silabus, RPP, Buku Suplemen, LKS, dan TKBKM yang sesuai strategi quick on the draw dengan masalah open ended pada materi prisma dan limas. Perangkat pembelajaran yang dihasilkan dalam tahap ini disebut dengan Prototipe 1.

Tahap test, evaluation and revition, dilakukan proses validasi, setelah itu dilakukan uji coba perangkat untuk mengetahui kepraktisan dan keefektifannya. Perangkat pembelajaran dalam bentuk prototipe 1 divalidasi oleh 5 validator, yaitu 3 orang dosen pendidikan matematika dan 2 orang guru matematika sampai mendapatkan perangkat yang valid. Hasil penilaian secara umum disajikan dalam Tabel 1.

Tabel 1. Rekapitulasi Nilai Validasi Perangkat Pembelajaran

\begin{tabular}{|c|c|c|c|c|c|c|c|c|c|}
\hline \multirow{2}{*}{ No } & \multirow{2}{*}{ Perangkat } & \multicolumn{5}{|c|}{ Validator } & \multirow{2}{*}{ Rerata } & \multirow{2}{*}{ Kriteria } & \multirow{2}{*}{ Ket. } \\
\hline & & I & II & III & IV & $\mathrm{V}$ & & & \\
\hline 1 & Silabus & 4,8 & 3,7 & 3,3 & 4,0 & 4,1 & 4,0 & Baik & Valid \\
\hline 2 & RPP & 4,9 & 4,0 & 3,5 & 4,4 & 4,2 & 4,2 & Baik & Valid \\
\hline 3 & Buku Suplemen & 4,9 & 3,9 & 4,0 & 4,3 & 4,4 & 4,3 & Sangat Baik & Valid \\
\hline 4 & LKS & 4,9 & 3,8 & 4,0 & 4,5 & 4,1 & 4,3 & Sangat Baik & Valid \\
\hline 5 & TKBKM & \multicolumn{8}{|c|}{$\begin{array}{l}\text { Berasarkan analisis butir soal meliputi validitas, reliabilitas, daya pembeda } \\
\text { dan tingkat kesukaran }\end{array}$} \\
\hline
\end{tabular}


Hasil

keterlaksanaan

pengamatan

pembelajaran diperoleh rerata skor 3,87 dari skor tertinggi 5,00 yang berarti termasuk dalam kriteria baik. Hasil angket respon siswa diperoleh data bahwa $81 \%$ siswa memberikan respon positif. Sedangkan hasil angket respon guru diperoleh rerata 4,12 dari skor tertinggi 5,00 yang berarti guru memberikan respon positif. Dengan demikian dapat disimpulkan bahwa perangkat pembelajaran yang dikembangkan praktis.

Selanjutnya untuk hasil uji keefektifan pembelajaran menggunakan perangkat yang dikembangkan, diketahui bahwa data nilai kemampuan berpikir kreatif matematis siswa berdistribusi normal dan memiliki varians yang homogen. Hasil yang diperoleh dari kelas uji coba perangkat pembelajaran adalah sebagai berikut: nilai rerata kemampuan berpikir kreatif $(\bar{x})=76$; nilai $\operatorname{KKM}\left(\mu_{0}\right)=70$; simpangan baku $(s)=6,56$; banyaknya siswa $n=22$. Berdasarkan analisis menggunakan uji $t$, maka nilai $t_{\text {hitung }}=4,29$, dengan $\alpha=5 \%$ dan $d k=21$ maka dari daftar distribusi $t$ diperoleh $t_{\text {tabel }}=1,72$. Dengan rumusan hipotesis $H_{0}$ adalah rerata kemampuan berpikir kreatif matematis siswa belum mencapai $\mathrm{KKM}(\mu \leq 70)$. Karena $t_{\text {hitung }}>t_{\text {tabel }}$ maka $H_{0}$ ditolak. Selain itu juga dilakukan uji proporsi menggunakan uji $z$ dengan data berikut: nilai siswa yang tuntas adalah $(x)=20$; jumlah siswa $(n)=22$; nilai proporsi yang dihipotesiskan $\left(\pi_{0}\right)$ $=75 \%$. Dengan rumusan hipotesis $H_{0}$ adalah banyaknya siswa yang mencapai KKM kurang dari atau sama dengan $75 \%(\pi \leq 75 \%)$. Diperoleh nilai $z_{\text {hitung }}=1,72$. Sementara itu dengan $\alpha=5 \%$ didapat $z_{\text {tabel }}$ atau $z_{0,45}=1,64$. Sehingga harga $z_{\text {hitung }}>z_{\text {tabel }}$ yang berarti $H_{0}$ ditolak.

Uji keefektifan yang kedua adalah untuk mengetahui perbedaan kemampuan berpikir kreatif matematis siswa. Hasil yang diperoleh dari kedua kelas adalah: nilai rerata kemampuan berpikir kreatif kelas pembelajaran strategi quick on the draw dengan masalah open ended $\left(\overline{x_{1}}\right)=76,02$; nilai rerata kemampuan berpikir kreatif kelas pembelajaran konvensional $\quad\left(\overline{x_{2}}\right)=71,8$; simpangan baku gabungan $(s)=$ 
6,01; jumlah siswa pembelajaran strategi quick on the draw dengan masalah open ended $\left(n_{1}\right)=22$; jumlah siswa pembelajaran konvensional $\left(n_{l}\right)=21$. Rumusan $H_{0}$ adalah rerata kemampuan berpikir kreatif matematis siswa yang diberi pembelajaran strategi quick on the draw dengan masalah open ended kurang dari atau sama dengan siswa yang diberi pembelajaran konvensional $\left(\mu_{1} \leq \mu_{2}\right)$. Dengan menggunakan uji $t$ maka nilai $t_{\text {hitung }}=2,30$, dengan $\alpha=5 \%$ dan $d k=41$ maka $t_{\text {tabel }}=t_{1-\alpha}=t_{0,95}=1,68$.

Sehingga harga $t_{\text {hitung }}>t_{\text {tabel }}$ yang berarti $H_{0}$ ditolak.

Uji keefektifan yang ketiga adalah untuk mengetahui perbedaan peningkatan kemampuan berpikir kreatif matematis siswa. Hasil yang diperoleh yaitu: nilai rerata peningkatan kemampuan berpikir kreatif siswa pembelajaran strategi quick on the draw dengan masalah open ended $\left(\overline{X_{1}}\right)=47,99$; nilai rerata peningkatan kemampuan berpikir kreatif siswa pembelajaran konvensional $\left(\overline{X_{2}}\right)=42,28 ;$ simpangan baku gabungan $(s)=6,94$; jumlah siswa pembelajaran strategi quick on the draw dengan masalah open ended $\left(n_{1}\right) \quad=22 ;$ jumlah siswa pembelajaran konvensional $\left(n_{2}\right)=$ 21. Dengan $H_{0}$ adalah rerata peningkatan kemampuan berpikir kreatif matematis siswa pembelajaran strategi quick on the draw dengan masalah open ended kurang dari atau sama dengan siswa pembelajaran konvensional $\left(\mu_{1} \leq \mu_{2}\right)$. Berdasarkan perhitungan, $\quad t_{\text {hitung }}=2,97$, dengan $\alpha=5 \%$ dan $d k=41$ maka $t_{\text {tabel }}=t_{1-\alpha}=t_{0,95}=1,68$.

Sehingga $t_{\text {hitung }}>t_{\text {tabel }}$ yang berarti $H_{0}$ ditolak.

Berdasarkan hasil penelitian tersebut, silabus dan RPP mempunyai karakteristik mengintegrasikan antara indikator yang harus dicapai yaitu dalam materi prisma dan limas dengan aspek kemampuan berpikir kreatif matematis. Langkah-langkah inti pembelajaran yang digunakan adalah: (1) menyampaikan tujuan pembelajaran dan memotivasi siswa; (2) menyajikan informasi; (3) mengorganisasikan siswa ke dalam kelompok belajar; membimbing kelompok belajar; (5) menyajikan masalah melalui kartu soal; (6) evaluasi; penghargaan.

Buku Suplemen mempunyai karakteristik berisi contoh soal dan 
pembahasan, juga latihan-latihan berbentuk masalah open ended. Contoh-contoh soal dan latihanlatihan yang ada dalam Buku Suplemen tersebut juga dikaitkan dengan aspek berpikir kreatif. LKS yang dikembangkan disesuaikan dengan tujuan pembelajaran untuk setiap pertemuan dan diintegrasikan dengan aspek-aspek berpikir kreatif. TKBKM berisi soal-soal mengenai materi yang diajarkan yaitu prisma dan limas, serta indikator pada materi tersebut dipadukan dengan aspek kemampuan berpikir kreatif. Saat pembelajaran, guru mengarahkan siswa untuk membentuk kelompok belajar, kelompok belajar ini sangat membantu siswa dalam mengerjakan LKS dan dalam kegiatan quick on the draw. Sebagian besar siswa aktif dalam kegiatan quick on the draw, penggunaan aturan untuk pengambilan kartu soal secara bergantian pada setiap kelompok menjadi salah satu faktor yang mengakibatkan siswa aktif. Buku Suplemen maupun LKS dapat direalisasikan dalam pembelajaran dengan baik. Siswa saling berdiskusi dalam mengerjakan LKS, dan Buku Suplemen menjadi salah satu sumber belajar dalam menyelesaikan LKS. Respon positif siswa mengindikasikan ketertarikan dan perasaan senang yang dirasakan siswa terhadap perangkat pembelajaran dan proses pembelajarannya. Selain itu, adanya respon positif guru cukup penting dalam mengetahui kepraktisan perangkat pembelajaran. Sebagai praktisi dalam kegiatan pembelajaran, guru tentunya harus mengetahui karakteristik siswa yang diajarnya, sehingga respon positif guru juga menandakan perangkat tersebut sangat sesuai.

Dengan pemberian masalah open ended siswa mulai terlatih untuk mengeluarkan gagasannya dan terbiasa menyelesaikan soal dengan beberapa cara, tidak terpaku kepada satu jawaban saja, jadi siswa dapat menentukan jawaban yang berbeda dengan cara yang sesuai dengan konsep yang telah dipelajari. Sullivan dkk (2013) menjelaskan bahwa dalam menyelesaikan masalah open ended siswa perlu mempertimbangkan konsep apa yang digunakan dalam menyelesaikan masalah dan juga siswa perlu mempertimbangkan kemungkinan beberapa jawaban. 
Penerapan pembelajaran quick on the draw mendorong kerja kelompok antar siswa sehingga dapat memudahkan siswa dalam mempelajari materi dan dalam menyelesaikan soal dari guru, dan berdampak pada kemampuan berpikir kreatif siswa. Penelitian Fitriansyah (2010) menyatakan bahwa pembelajaran dengan strategi quick on the draw dapat meningkatkan hasil belajar siswa, selain itu juga bisa menjalin kerja kelompok dengan baik dan dapat memberikan motivasi agar lebih giat lagi belajar. Materi prisma dan limas yang merupakan bagian dari geometri merupakan bagian materi yang cukup sulit bagi siswa. Pembelajaran kelompok yang bersifat kooperatif ini cukup membantu siswa dalam memahami materi prisma dan limas yang merupakan bagian dari geometri. Hal tersebut juga sesuai pendapat Najafi dkk (2012) bahwa metode pembelajaran kooperatif dapat meningkatkan keterampilan pemecahan masalah geometri, dan metode pembelajaran aktif ini tepat untuk siswa khususnya dalam pembelajaran geometri. Dengan pembelajaran quick on the draw yang menekankan pada pembelajaran kelompok, sehingga dalam mempelajari prisma dan limas menjadi lebih mudah bagi siswa.

\section{KESIMPULAN DAN SARAN}

Perangkat pembelajaran matematika strategi quick on the draw dengan masalah open ended matematis valid dan praktis, serta efektif dalam meningkatkan kemampuan berpikir kreatif matematis siswa pada materi prisma dan limas.

Berdasarkan hasil penelitian ini, terdapat beberapa hal yang peneliti sarankan yaitu pengembangan Perangkat pembelajaran strategi quick on the draw dengan masalah open ended hendaknya juga dikembangkan untuk pokok bahasan lain dalam mata pelajaran matematika, (2) pemberian masalah open ended perlu diberikan dengan bimbingan yang intensif dari guru dan perlu dilakukan secara berkala agar siswa terbiasa mengeluarkan ide mereka dalam beragam jawaban sehingga siswa juga akan terbiasa berpikir kreatif.

\section{DAFTAR PUSTAKA}

Chamberlin, M. 2009. "Teachers' Reflections on their Mathematical Learning 
Experiences in a Professional Development Course". Mathematics Teacher Education and Development. Volume 11. Hal 22-35.

Dhlamini, J., \& Mogari, D. 2013. "The effect of a group approach on the performance of high school mathematics learners". Pythagoras. Vol 34 No. 2. Hal 1-9.

Fitriansyah. 2010. "Upaya Meningkatkan Hasil Belajar Matematika Siswa SMP Negeri 3 Belawang melalui Strategi Pembelajaran Quick on the Draw". Jurnal Edukasi Matematika. Vol 1 No. 2.Hal 1621.

Ginnis, P. 2008. Trik \& Taktik Mengajar Strategi Meningkatkan Pencapaian Pengajaran di Kelas. Terjemahan Wasi Dewanto. Jakarta: PT. Indeks.

Kattou, M, dkk. 2012. "Connecting mathematical creativity to mathematical ability". ZDM. Vol 45 No. 2. Hal 167-181.

Kwon, O.N., Park. J.S., \& Park. J.H. 2006. "Cultivating Divergent Thinking in Mathematics through an Open-Ended Approach". Asia Pacific Education Review. Vol 7 No.1. Hal 51-61.

Levav, W. A., \& Leikin, R. 2009. "Multiple solutions for a problem: A tool for evaluation of mathematical thinking in geometry". Dalam Guerrier, V.
D., Lavergne, S. S., dan Arzarello, F. (Ed.), Proceedings of sixth conference of European Research in Mathematics Education. Lyon: Institut National de Recherche Pe'dagogique. Hal 776-785.

Mahmudi, A. 2010. Mengukur Kemampuan Berpikir Kreatif Matematis. Makalah. Konferensi Nasional Matematika XV di UNIMA..

Mason, M., dkk. 2004. Geometry For Middle School Teachers. Virginia: Virginia Department of Education.

Mullis, I. V. S., dkk. 2012. TIMSS 2011 International Results in Mathematics. United States: TIMSS \& PIRLS International Study Center.

Najafi, M., Amiripour, P., \& Sahahvarani, A. 2012. Application of cooperative learning method in geometry instruction. International Journal of Emerging Trends in Engineering and Development. Vol 2 No.2. Hal 155-163.

Nieveen, N. 2007. "Formative Evaluation in Educational Design Research". Dalam Plomp, T., dan Nieveen, N. An Introduction to Educational Design Research. Proceedings of the seminar conducted at the East China Normal University, Shanghai (PR China). SLO Netherlands Institute for Curriculum Development. 
Pehkonen, E. 2007. Problem solving in mathematics education in Finland.

http://www.unige.ch/math/EnsM ath/Rome2008/WG2/Papers/PE

HKON.pdf. (Diunduh pada 24 Januari 2014).

Rochmad. 2012. "Desain Model Pengembangan Perangkat Pembelajaran Matematika". Kreano. Vol 3 No. 1. Hal 59-72.

Rochmad. 2013. Keterampilan Berpikir Kritis Dan Kreatif Dalam Pembelajaran Matematika. Makalah. Seminar Nasional Matematika di UNNES. Semarang, 26 Oktober.

Siswono, T.Y.E. 2009. Pengembangan Model Pembelajaran Matematika Berbasis Pemecahan dan Pengajuan Masalah untuk Meningkatkan Kemampuan Berpikir Kreatif Siswa. Makalah Simposium Pusat Penelitian Kebijakan Dan Inovasi Pendidikan Badan Penelitian Dan Pengembangan Depdiknas.

Smith, T. J., McKenna, C. M., \& Hines, E. 2013. "Association of group learning with mathematics achievement and mathematics attitude among eighth-grade students in the US". Learning Environments Research.

Sriraman, B., Yaftian, N., Lee, K. H. 2011. "Mathematical Creativity And Mathematics Education". Dalam Sriraman, B and Lee, K.H. (ed.). The Elements of Creativity and Giftedness in
Mathematics. Sense Publishers. Hal 119-130.

Sudiarta, $\quad$ I.G.P. 2006. "Pengembangan dan Implementasi Pembelajaran Matematika Berorientasi Pemecahan Masalah Kontekstual Open-Ended untuk Siswa Sekolah Dasar". Jurnal Pendidikan dan Pengajaran UNDIKSHA. Edisi Khusus Desember.

Sullivan, P., Clarke, D., dan Clarke, B. 2013. Teaching with Tasks for Effective Mathematics Learning, Mathematics Teacher Education 9. New York: Springer.

Trianto. 2009. Mendesain Model Pembelajaran Inovatif-Progresif Konsep, Landasan, dan Implementasinya pada Kurikulum Tingkat Satuan Pendidikan (KTSP). Jakarta: Kencana. 